\begin{tabular}{llll}
\hline UNIVERSITAS & RACIC 6(1)(2021) \\
JBDURRAB & Jttp://jurnal.univrab.ac.id/index.php/racic \\
\hline
\end{tabular}

\title{
IDENTIFIKASI JENIS-JENIS KERUSAKAN JALAN (PERKERASAN LENTUR) STUDI KASUS JALAN LINTAS TALUK KUANTAN - BATAS PROVINSI SUMATERA BARAT
}

\author{
Toyip Setiawan ${ }^{1}$, Winayati ${ }^{2}$, Fitridawati Soehardi ${ }^{3 *}$ \\ Program Studi Teknik Teknik Sipil, Fakultas Teknik, Universitas Lancang Kuning \\ J1. Yos Sudarso Km.8 Rumbai Pekanbaru \\ Telp (0761) 53108-53236 \\ Alamat e-mail ${ }^{1}$ toyib.setiawan92@gmail.com, ${ }^{2}$ winayati@ unilak.ac.id, ${ }^{3}$ fitridawati@unilak.ac.id
}

\begin{abstract}
Info Artikel
Abstrak

Sejarah Artikel:

Ruas Jalan Taluk Kuantan - Batas Provinsi Sumatera Barat merupakan salah satu ruas jalan alternatif yang dapat menghubungkan tiga provinsi yaitu, Provinsi Riau, Provinsi Sumatera Barat, dan Provinsi Jambi. Jalan tersebut merupakan

Diterima : 19 Desember 2020 Disetujui : 29 Juni 2021 jalan Nasional (lintas tengah) dengan jumlah LHR yang cukup tinggi, sehingga mengakibatkan kerusakan pada badan jalan. Tujuan penelitian ini untuk Dipublikasikan :30 Juni 2021 menentukan nilai tingkat kerusakan lapisan perkerasan lentur untuk mengetahui jenis dan tingkat kerusakan yang terjadi serta menentukan jenis pemeliharaan yang sesuai. Metode yang digunakan adalah metode Asphalt institute, untuk

Keywords: menentukan nilai kondisi perkerasan (Pavement Condition Rating) PCR. Hasil penelitian diketahui bahwa jenis kerusakan yang terdapat pada jalan ini antara

Jenis kerusakan, Tingkat kerusakan, PCR buaya $0,312 \%$, retak blok $0,297 \%$, retak berkelok $0,149 \%$, retak pinggir $1,379 \%$, butiran lepas $0,120 \%$, kegemukan $0,043 \%$, aus/agregat licin 2,397\%, terkelupas $0,126 \%$, lubang $0,030 \%$. Persentase total kerusakan jalan di sepanjang lokasi penelitian adalah: 9,05\%, Nilai Indeks Kondisi kerusakan jalan menurut metode Asphalt Institute adalah 90,95\%. Sehingga diperlukan pemeliharaan rutin seperti, pengisian retak, menutup lobang (patching).
\end{abstract}

Kata Kunci: Jenis kerusakan, Tingkat kerusakan, PCR.

\section{Abstract}

The Taluk Kuantan - West Sumatra Province Boundary Road is one of the alternative roads that can connect three provinces, namely Riau Province, West Sumatra Province, and Jambi Province. The road is a national road (middle cross) with a fairly high number of LHR causing damage to the road body. The purpose of this study was to determine the value of the level of damage to the flexible pavement layer to determine the type and level of damage that occurred and to determine the appropriate type of treatment. The method used is the Asphalt Institute method, to determine the PCR Pavement Condition Rating value. The results showed that the types of damage found on this road segment include $2.303 \%$ subsidence, $1.499 \%$ sungkur, $0.395 \%$ longitudinal crack, $0.312 \%$ 


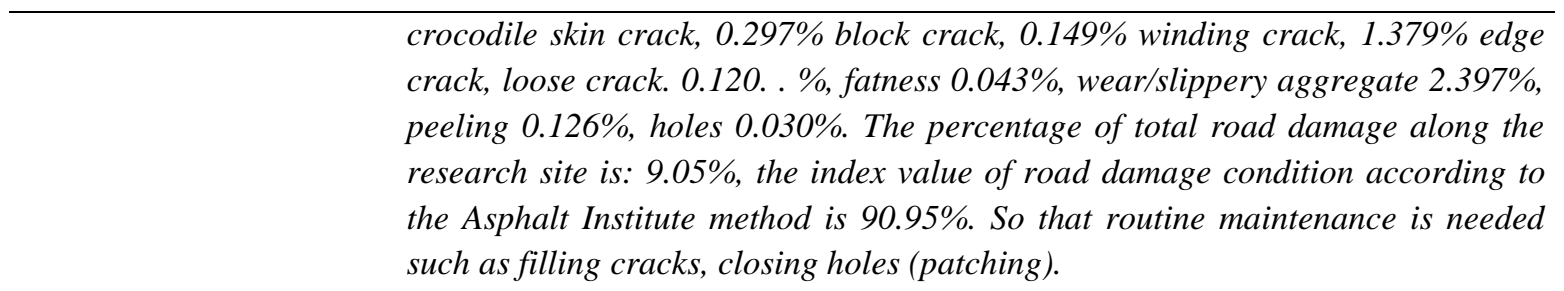

Keywords: Damage type, Damage level, PCR

(C) 20xx Universitas Abdurrab

Alamat korespondensi:

Jl. Yos Sudarso Km.8

Rumbai Pekanbaru

E-mail: fitridawati@unilak.ac.id

\section{PENDAHULUAN}

Jalan merupakan suatu prasarana perhubungan darat dalam bentuk maupun meliputi segala bagian jalan termasuk bangunan pelengkap dan pelengkapnya yang diperuntukkan bagi lalu lintas [1][2]. Kelancaran kegiatan hubungan perekonomian, sosial, budaya maupun politik suatu wilayah tidak terlepas dari peranan penting jalan sebagai sarana perhubung antara satu daerah ke daerah yang lain, salah satunya adalah Jalan Taluk Kuantan - Batas Provinsi Sumatera Barat yang merupakan salah satu ruas jalan alternatif yang dapat menghubungkan 3 (tiga) provinsi yaitu, Provinsi Riau, Provinsi Sumatera Barat dan Provinsi Jambi. Jalan tersebut merupakan jalan nasional (lintas tengah), dimana lebarnya masih dibawah standar untuk jalan nasional sesuai PP nomor 34 tanuh 2006 dan terdapat banyak kerusakan pada badan jalan.

Kondisi Jalan Lintas Taluk Kuanttan - Batas Provinsi Sumatera Barat ini mengakibatkan terjadinya permasalahan kerusakan jalan. Permasalahan ini sudah dilakukan upaya mengatasinya oleh pemerintah dengan merencanakan pemeliharaan rutin setiap tahunnya, namun keterbatasan anggaran dana maka pelaksanaan rencana pemeliharaan tersebut tidak sepenuhnya bisa terpenuhi pada semua ruas jalan oleh instansi terkait. Pada survei pendahuluan yang dilakukan penulis pada jalan ini terdapat kerusakan, seperti kerusakan retak kulit buaya, pengelupasan, ambles dan kerusakan lubang yang terdapat pada STA $12+150-14+275$.

\section{TINJAUAN PUSTAKA}

\section{Pengertian Lapisan Perkerasan}


Perkerasan jalan merupakan suatu sistem terdiri dari beberapa lapis material yang dibangun di atas lapisan tanah paling dasar, dan mempunyai fungsi memberikan tampilan permukaan yang rata dan mempunyai tingkat kekesatan tertentu, serta diharapkan memiliki umur layanan yang pajang panjang dengan pemeliharaan dengan tingkat minimum [3]

Menurut Sukirman,S.(1999)[4], perkerasan lentur [5] dapat dibedakan menjadi 3 jenis berdasarkan bahan pengikat yang digunakan dalam membentuk lapisan bagianatas perkerasan jalan antara lain:

1. Perkerasan lentur (fleksible pavement) merupakan jenis perkerasan dengan bahan penggikatnya menggunakan aspal. fungsi Lapisan-lapisan perkerasannya mempunyai sifat menyebarkan beban dan memikul beban ketanah dasar.

2. Perkerasan kaku (rigid pavement) merupakan perkerasan dengan bahan pengikatnya menggunakan semen (portland cement). Perkerasan kaku dalam bentuk Pelat beton dengan atau tanpa tulangan diletakkan di bagian atas tanah dasar dengan atau tanpa lapis pondasi bawah. Beban lalu lintas sebagian besar dipikul oleh pelat beton.

3. Perkerasan komposit (composite pavement) merupakan perkerasan kaku yang dikombinasikan penggunaanya dengan perkerasan lentur. contoh penggunaanya dapat berupa perkerasan lentur dibagian atas perkerasan kaku atau kebalikannya perkerasan kaku dibagian atas perkerasan lentur.

\section{Jenis Jenis Kerusakan Perkerasan Lentur}

Kerusakan perkerasan lentur salah satunya dapat disebabkan oleh kadar pori argegat, dimana kadar pori aggregat mempengaruhi kadar aspal yang terserap [6][7]. Jenis-jenis kerusakan yang pada umumnya terjadi perkerasan lentur dapat diklarifikasikan menjadi 5 jenis antara lain [3][8][2][9][10],:

1. Deformasi, diantaranya bergelombang, alur, ambles, sungkur, mengembang, benjol dan turun.

2. Retak, diantaranya memanjang, melintang, diagonal, berkelok-kelok, kulit buaya, blok, selip.

3. Kerusakan di pinggir perkerasan, diantaranya pinggir retak/pecah dan bahu jalan turun.

4. Kerusakan terkstur permukaan diantaranya butiran lepas, kegemukan, agregat licin, pengelupasan, stripping.

5. Kerusakan lubang, tambalan. 


\section{METODE}

Lokasi penelitian adalah jalan lintas Taluk Kuantan-Batas Sumatera Barat, lokasi penelitian adalah STA 12+125 - STA 14+275 atau sepanjang 2.150 m yang terletak di Kecamatan Gunung Toar, Kabupaten Kuantan Singingi. Data primer merupakan data yang diperoleh langsung dari hasil survei dilapangan yaitu gambar kerusakan, dimensi kerusakan, jenis-jenis kerusakan[11][12]. Data sekunder merupakan data yang diperoleh berdasarkan sumber referensi data yang telah ada baik dari instansi terkait berupa Data panjang dan lebar jalan dan status jalan. Setelah diketahui volume luasan dimensi untuk setiap tipe kerusakan kemudian akan didapat nilai kerusakan berupa persentase luas dari satu jenis kerusakan terhadap luas total bagian jalan yang diukur, bisa dalam feet (ft) atau meter $(\mathrm{m})$, sehingga nilai kerapatan kerusakan dapat dihitung menggunakan persamaan :

$\%$ kerusakan $=\underline{\text { luas kerusakan }} \times 100$

Luas jalan

\section{HASIL DAN PEMBAHASAN}

\section{Hasil Identifikasi Tingkat Kerusakan Jalan}

Data hasil survei kondisi jalan Jalan lintas Taluk Kuantan - Batas Sumatera Barat STA 12+125

- STA 14+275 diperoleh panjang jalan 2150 m, lebar jalan 6 m. Data kerusakan-kerusakan akan ditinjauan per STA $\pm 100 \mathrm{~m}$ dengan hasil pengamatan $\pm 1 \mathrm{KM}$ sebagai berikut :

Tabel 1. Hasil Persentase Tingkat Kerusakan Jalan

\begin{tabular}{c|l|l|l}
\hline \multicolumn{1}{c|}{ STA } & \multicolumn{1}{|c|}{$\begin{array}{c}\text { Total Luasan } \\
\text { Kerusakan }\end{array}$} & $\begin{array}{c}\text { Luas Jalan } \\
\text { Penelitian }\end{array}$ & \multicolumn{1}{c}{$\begin{array}{c}\text { Persentase } \\
\text { Kerusakan Jalan }\end{array}$} \\
\hline STA $12+125-$ STA $13+125$ & $914,71 \mathrm{~m}^{2}$ & $6000 \mathrm{~m}^{2}$ & $15,245 \%$ \\
\hline STA $13+125-$ STA $14+125$ & $252,73 \mathrm{~m}^{2}$ & $6000 \mathrm{~m}^{2}$ & $4,212 \%$ \\
\hline STA $14+125-$ STA $14+175$ & $\begin{array}{l}\text { Tidak Ada } \\
\text { Kerusakan }\end{array}$ & - & - \\
\hline
\end{tabular}

Berdasarkan data tabel 1 diperoleh total kerusakan jalan pada Jalan lintas Taluk Kuantan Batas Sumatera Barat STA $12+125$ - STA $14+275$ adalah 19,457\%, namun pada STA $14+125$ - STA $14+175$ kondisi jalan masih layak digunakan karena tidak ditemukan kerusakan pada jalan.

Analisa Jenis-Jenis Kerusakan Jalan STA 12+125 - STA 14+275 dengan Metode Asphalt Institute 
Setelah dilakukan analisa dilokasi penelitian pada ruas jalan lintas Taluk Kuantan-Batas sumatera Barat STA 12+125 - STA 14+275 sepanjang $2150 \mathrm{~m}$ tersebut banyak mengalami kerusakan, baik tingkat kerusakan ringan, kerusakan sedang maupun kerusakan berat adapun tingkat kerusakan berdasarkan kriteria yang mengacu pada Shahin (1994) dan AUSTROADS (1987) dalam (Hary Christady Hardiyatmo,2007)[3] . Jenis-jenis kerusakan yang terjadi sepanjang jalan Lintas Taluk Kuantan-Batas sumatera Barat STA 12+125 - STA 14+275 antara lain :

Tabel 2. Hasil Persentase jenis -jenis Kerusakan Jalan

\begin{tabular}{llll}
\hline \multicolumn{1}{c}{ Jenis Kerusakan } & Total Luas Kerusakan & $\begin{array}{c}\text { Luas Jalan } \\
\text { Penelitian }\end{array}$ & $\begin{array}{c}\text { Persentase } \\
\text { Kerusakan Jalan }\end{array}$ \\
\hline Ambles (Depression) & $297,08 \mathrm{~m}^{2}$ & $12.900 \mathrm{~m}^{2}$ & $2,303 \%$ \\
\hline Sungkur (Shoving) & $193,33 \mathrm{~m}^{2}$ & $12.900 \mathrm{~m}^{2}$ & $1,499 \%$ \\
\hline $\begin{array}{l}\text { Retak Memanjang } \\
\text { (longitudinal cracks) }\end{array}$ & $50,93 \mathrm{~m}^{2}$ & $12.900 \mathrm{~m}^{2}$ & $0,395 \%$ \\
\hline Retak Kulit Buaya ( Alligator & $40,26 \mathrm{~m}^{2}$ & & $0,312 \%$ \\
Cracks) & & $12.900 \mathrm{~m}^{2}$ & \\
\hline Retak Block (Block Cracks) & $38,34 \mathrm{~m}^{2}$ & $12.900 \mathrm{~m}^{2}$ & $0,297 \%$ \\
\hline $\begin{array}{l}\text { Retak Berkelok ( Meandering } \\
\text { Cracks) }\end{array}$ & $19,18 \mathrm{~m}^{2}$ & $12.900 \mathrm{~m}^{2}$ & $0,149 \%$ \\
\hline Retak Pinggir (Edge Cracks) & $177,93 \mathrm{~m}^{2}$ & $12.900 \mathrm{~m}^{2}$ & $1,379 \%$ \\
\hline Butiran Lepas ( Raveling) & $15,54 \mathrm{~m}^{2}$ & $12.900 \mathrm{~m}^{2}$ & $0,120 \%$ \\
\hline Kegemukan (Bleeding) & $5,52 \mathrm{~m}^{2}$ & $12.900 \mathrm{~m}^{2}$ & $0,043 \%$ \\
\hline Pengelupasan & $16,27 \mathrm{~m}^{2}$ & $12.900 \mathrm{~m}^{2}$ & $0,126 \%$ \\
\hline Aus Atau Agregat Licin & $309,20 \mathrm{~m}^{2}$ & $12.900 \mathrm{~m}^{2}$ & $2,397 \%$ \\
(Polished Agregat) & & & $0,03 \%$ \\
\hline lubang (potholes) & $3,86 \mathrm{~m}^{2}$ & $12.900 \mathrm{~m}^{2}$ & \\
\hline & & & \\
\hline
\end{tabular}

Berdasarkan tabel 2 diperoleh Persentase total kerusakan jalan di sepanjang jalan Lintas Taluk Kuantan-Batas sumatera Barat STA 12+125 - STA 14+275 adalah: 9,05 \%, dengan persentase kerusakan terparah berdasarkan jenis kerusakannya ialah Aus Atau Agregat Licin (Polished Agregat) sebesar 2,397 \%. Hal ini disebabkan jalan mengalami ausnya agregat permukaan akibat lalu lintas sehingga permukaan cendrung menjadi lebih licin. terutama sesudah hujan, sehingga membahayakan kendaraan. 
Jenis-jenis kerusakan yang terjadi sepanjang jalan Lintas Taluk Kuantan-Batas Sumatera Barat STA 12+125 - STA 14+275 per $100 \mathrm{~m}$. Dpat dilihat pada gambar-gambar dibawah ini

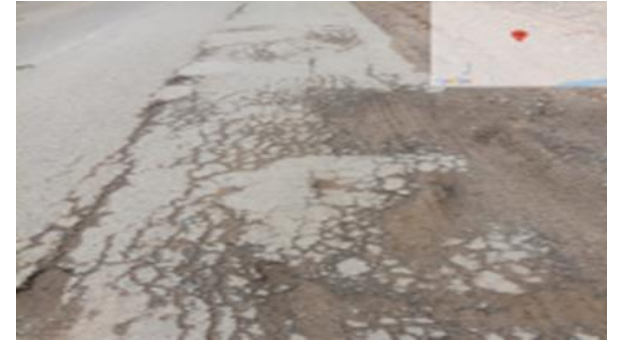

Gambar 1. Jenis Kerusakan Retak Pinggir

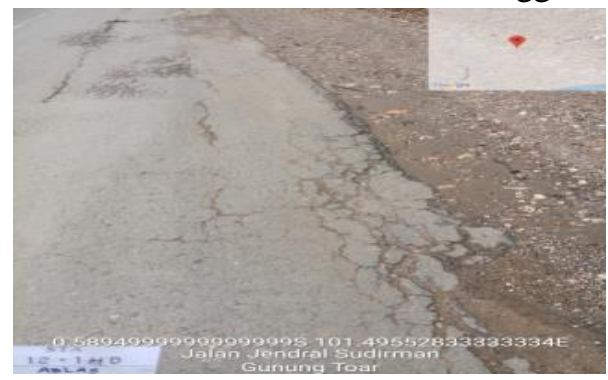

Gambar 3. Penurunan Perkerasan

Berbentuk Ambles
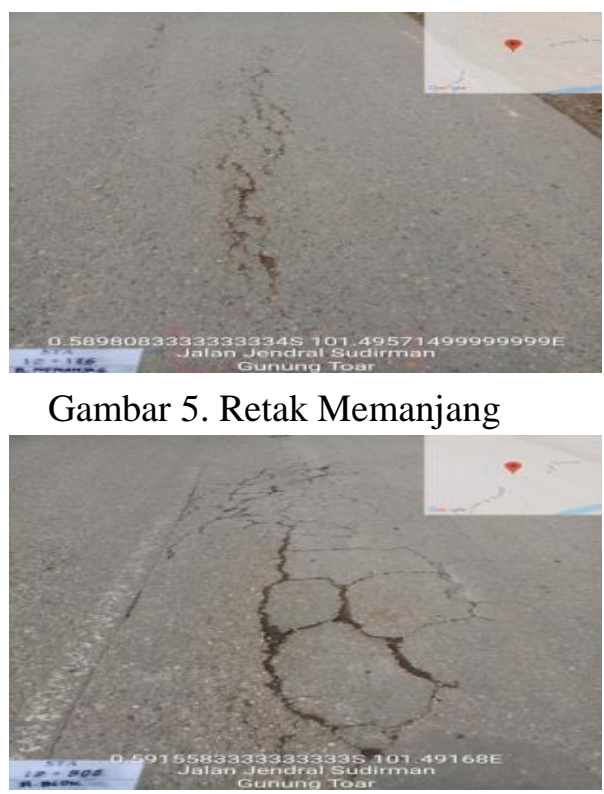

Gambar 7. Retak Blok

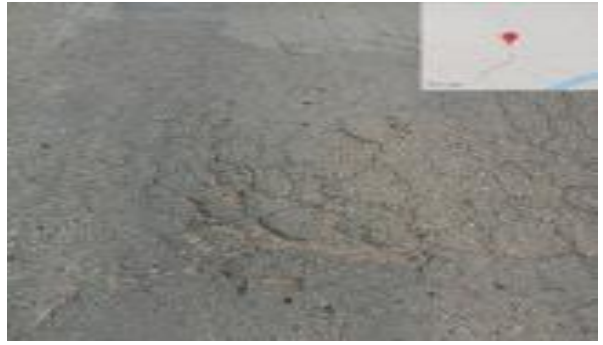

Gambar 2. Jenis Kerusakan Retak Kulit Buaya

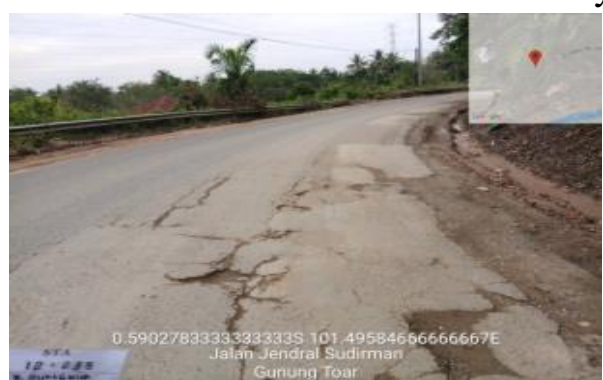

Gambar 4. Deformasi Plastis pada Tikungan Tajam

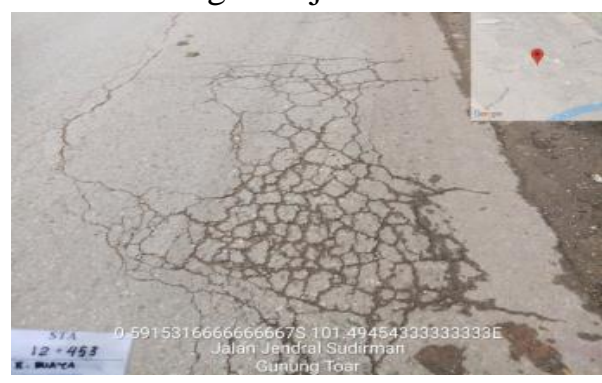

Gambar 6. Retak Kulit Buaya

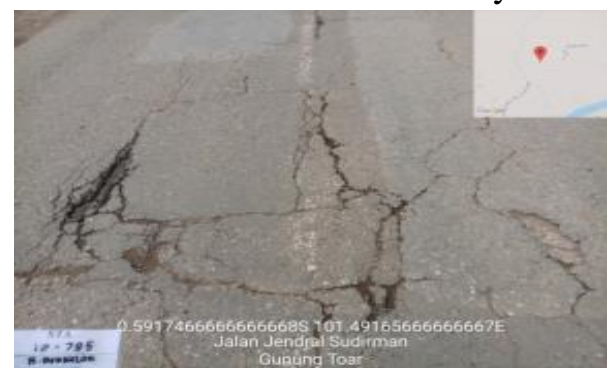

Gambar 8. Retak Berkelok 


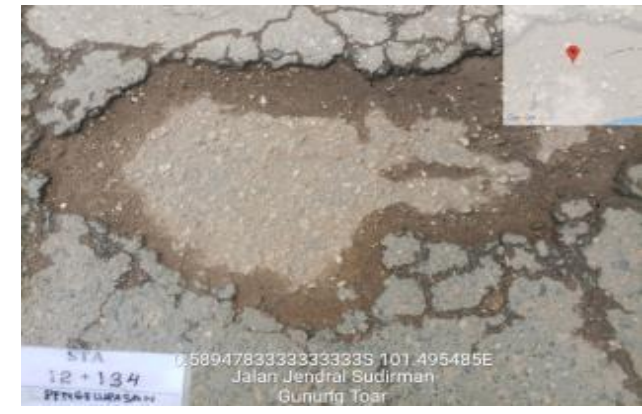

Gambar 9. Pengelupasan (Delamination)

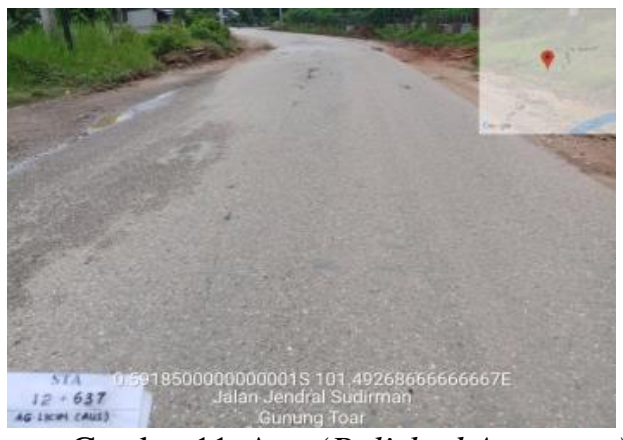

Gambar 11. Aus (Polished Aggregat)

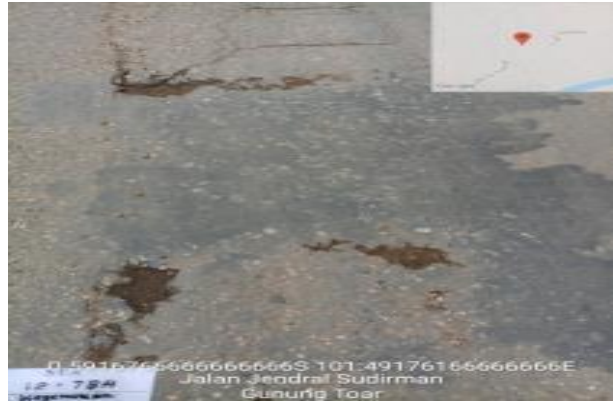

Gambar 10. Kegemukan (Bleeding)

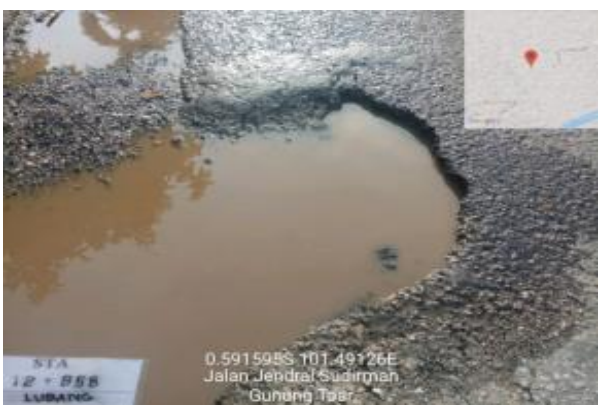

Gambar 12. Lubang (Potholes)

Berdasarkan Gambar 1 s/d gambar 12 menunjukkan jenis-jenis kerusakan jalan pada Jalan lintas Taluk Kuantan - Batas Sumatera Barat STA 12+125 - STA 14+275 antara lain Ambles (Depression), Sungkur (Shoving), Retak Memanjang (longitudinal cracks), Retak Kulit Buaya (Alligator Cracks), Retak Block (Block Cracks), Retak Block (Block Cracks), Retak Berkelok (Meandering Cracks), Retak Pinggir (Edge Cracks), Kegemukan (Bleeding), Pengelupasan. Kerusakan kerusakan jalan ini dapat disebabkan oleh pemakaiaan kadar aspal yang tinggi pada campuran,, pemakaiaan banyak aspal pada pekerjaan primcoat dan tack coat sehingga menjadi licin dan pengaruh suhu pada campuran aspal [13]

\section{SIMPULAN}

Berdasarkan hasil penelitian kerusakan jalan Lintas Taluk Kuantan-Batas Sumatera Barat STA 12+125 - STA 14+275 yang terletak di Kecamatan Gunung Toar Kabupaten Kuantan Singingi maka dapat diambil kesimpulan :

1. Persentase total kerusakan jalan di sepanjang lokasi penelitian adalah: $9,05 \%$, dengan persentase kerusakan terparah berdasarkan jenis kerusakannya ialah kerusakan aus / agregat licin sebesar 2,397\%. 
2. Hasil identifikasi jenis kerusakan jalan di sepanjang lokasi penelitian adalah ambles, sungkur, retak memanjang, retak kulit buaya, retak blok, retak berkelok-kelok, retak pinggir, butiran lepas, kegemukan, aus/agregat licin, terkelupas dan lubang.

\section{UCAPAN TERIMA KASIH}

Ucapan terima kasih kepada para pembimbingku dan pihak terkait yang telah membantu dan bekerjasama demi kelancaran penelitian ini.

\section{DAFTAR PUSTAKA}

[1] Departemen Pekerjaan Umum, Undang-Undang No 13 Tahun 1980 Tentang Jalan. 1980.

[2] Mardianus, "Kerusakan Perkerasan Jalan ( Studi Kasus: Jalan Kuala Dua Kabupaten Kubu Raya ),” J. Tek. Sipil UNTAN, vol. 13, no. 1, pp. 149-160, 2013.

[3] H. C. Hardiyatmo, Pemeliharaan Jalan Raya, 2nd ed. Yogyakarta: Nova, 2007.

[4] S. Sukirman, Perkerasan Lentur Jalan Raya, 1st ed. Bandung: Nova, 1999.

[5] I. Waldenhoff, S. Napitu, and S. J. Raya, "Kerusakan yang Timbul pada Jalan Raya Akibat Beban Angkutan yang Melebihi dari yang Ditetapkan,” J. Sist. Tek. Ind., vol. 7, no. 2, pp. 104-108, 2006.

[6] L. D. Putri, S. Wiyono, and A. Puri, "Kajian Kadar Aspal Hasil Ektraksi Penghamparan dan Mix Design Pada Campuran Asphalt Wearing ConCrete Course ( Acwc) Gradasi Halus,” in Annual Civil Engineering Seminar 2015, 2015, vol. 2, pp. 978-979.

[7] M. Anggraini et al., "KAJIAN KADAR ASPAL HASIL EKSTRAKSI PENGHAMPARAN CAMPURAN AC-WC GRADASI KASAR DENGAN," Annual Civil Engineering Seminar 2015, vol. 2, pekanbaru, pp. 978-979, Sep-2015.

[8] M. Refiyanni, S. M. Saleh, and M. Isya, "Evaluasi penanganan kerusakan konstruksi jalan berdasarkan jenis konstruksi dan beban lalu lintas," J. Tek. Sipil Pascasarj. Univ. Syiah Kuala, vol. 3, no. 3, pp. 117-127, 2014.

[9] A. Munandar, S. Widodo, and E. Sulandari, "Analisa Kondisi Kerusakan Jalan Pada 
Lapis Permukaan (Studi Kasus : Jalan Adi Sucipto Sungai Raya Kubu Raya),” J. Mhs. Tek. Sipil Univ. Tanjungpura, vol. III, no. 2, pp. 1-11, 2014.

[10] F. Chasanah and D. A. Wijaya, "Evaluasi Tingkat Kerusakan Perkerasan Lentur dengan Metode Paverment Cobdition Index (PCI) untuk Menentukan Prioritas Penanganan Pada Jalan Solo-Yogyakarta Km 43,8 - 44,8," in Proceedings of the 19th International Symposium of FSTPT Islamic University of Indonesia, 2016, no. October, pp. 278-287.

[11] H. F. Betaubun and J. Paresa, “Analisa Kerusakan Jalan Menggunakan Metode Pci Dan Asphalt Institute Ms-17,” Mustek Anim Ha, vol. 8, no. 2, pp. 121-131, 2019.

[12] S. R. Hidayat and R. Santosa, "Kajian Tingkat Kerusakan Menggunakan Metode PCI Pada Ruas Jalan Ir. Sutami Kota Probolinggo,” Ge-STRAM J. Perenc. dan Rekayasa Sipil, vol. 1, no. 2 , p. 65,2018 .

[13] F. Yudaningrum and I. Ikhwanudin, "IDENTIFIKASI JENIS KERUSAKAN JALAN (Studi Kasus Ruas Jalan Kedungmundu-Meteseh),” Teknika, vol. 12, no. 2, pp. 16-23, 2017. 